\title{
Digital and Scientific Literacy with Games: A Pedagogical Process Based on System Engineering
}

\author{
Ana Paula Cavadas Rodrigues[Colégio Estadual Marechal Zenóbio da Costa SEEDUC/RJ | anapcavadas@gmail.com ] \\ Raquel Moreira Machado Fernandes (D [ Universidade Federal do Rio de Janeiro | raquel.fernandes.2@cp2.edu.br ] \\ Leniah Lima Teixeira [Iniciação científica da Universidade Federal do Rio de Janeiro | leniahlima@gmail.com ] \\ Gabrielle Bandeira Alves [ Colégio Estadual Marechal Zenóbio da Costa - RJ | gabriellealves.baa@gmail.com ] \\ Carlo Emmanoel Tolla de Oliveira (i) [Universidade Federal do Rio de Janeiro | carlo@nce.ufrj.br ] \\ Claudia Lage Rebello da Motta (iD [Universidade Federal do Rio de Janeiro | claudiam@nce.ufrj.br ]
}

\begin{abstract}
This study presents a Brazilian teaching-learning experience in basic education where game development is used to promote both digital and scientific literacy throughout the National Common Curricular Base (BNCC). Focused on students' cognitive aspects, the approach presents a pedagogical architecture based on systems development. Thus, it was possible to catalyze convergence between interest in the Science curricular program and the result of knowledge acquisition - such as skills development - by its means. The experiment was carried out centered on genetics studies where students collaboratively produced a digital game, improving in school assessment performance as an outcome. Therefore, we corroborate the effectiveness of creating games as an educational strategy able to optimize aspects of creativity, communication, collaboration, logical reasoning, problem-solving, abstract thinking and resilience.
\end{abstract}

Keywords: Games, digital literacy, scientific literacy, cognitive aspects, educational innovation

\section{Introduction}

Current perspectives in science education point to the need for skills development promotion, allowing students to understand the world and act as individuals in society. A complete citizen is someone who is capable of using his or her knowledge connecting science with technology in favor of mankind. This holistic approach of education is necessary for students and teachers to understand the impact of technology in nature, culture and humanity.

The National Common Curricular Base (BNCC) brings the concept of scientific literacy, which involves the ability of world comprehension and transformation based on sciences' theoretical and procedural contributions. This experience aims to promote scientific literacy through digital culture, using games as a catalyst in the convergence between interest induced by the Science curricular program and demonstrative apprehension of knowledge acquired through it as well as encouraging youth protagonism - as proposed by $B N C C$ - through problem-solving in game development.

This paper presents an extended version of the work entitled $A$ teaching-learning experience of classical genetics through games in education (Free Translation), where we presented the development of game as a promising strategy for the teaching-learning processes in Brazilian basic education context. Our work was dedicated to middle school and high school, but also integrated higher education students and researcher into the activities.

We are now engaged in detailed aspects of the pedagogical process based on systems engineering and how game development can improve teaching-learning process and science knowledge.

We use the game approach as a pedagogical strategy proposed by Rodrigues et al. (2019), which can help to promote literacy and digital fluency in a constructionist perspective where students can build and program their own games, activating and developing cognitive functions.

Thus, we present an account on the project's experience in game developing for teaching-learning of genetics, a curricular component of basic education, according to the $B N C C$.

Before justifying our initiative, it is important to contextualize basic education in Brazil. The basic education comprises all segments: elementary school, middle school and high school. National Curriculum Parameters (PCN) for elementary and middle school state that Natural Sciences teaching has been conducted in an uninteresting, little understandable way. Despite its importance, interest it can awaken and the variety of topics that it involves, it has been taught without direct interaction with natural or technological phenomena, which ends up leaving a huge gap in student's learning acquisition.

The statement that knowledge-based verification does not reflect the interest determined by young people can also be proven by the result of a recent research in Youth Science, carried out by "Financier of Studies and Projects" with young people from public and private schools in the age group of 12 to 17 years. The survey revealed that $64 \%$ of the participants understand Science as important for their day-to-day activities. It also considered the subject to be the one that awoke the greatest interest among the participants. However, according to most recent data from the Program 
for International Student Assessment (PISA), Brazil could not register significant advances in student performance, reaching 489 points in Science, an average considered low among the Organization for Economic Cooperation and Development partner countries (OECD).

Fialho and Mendonça (2020) developed an analysis of the PISA indicators from 2006, showing that the government should develop public policies to improve teaching of Sciences, which, according to the authors, is in the background in comparison to Portuguese and Mathematics. This gap in Brazilian education justifies our need to explore new process and methodologies to teach Science.

The motivation for this work was the result of a survey with the students, where they demonstrated a generalized difficulty in understanding classical genetics.

Among the perceived difficulties, we highlighted trouble understanding vocabulary, terminology, and, also, mathematical content related to Mendel's Laws, among others. Although the students showed a reasonable interest in the subject, the learning performance was below expectations. The expositive and traditional classes were taxing the students beyond their capacity of keeping the initial aroused enthusiasm for genetics.

The solution devised was to develop a new methodology that could keep the momentum acquired at the initial contact with the new science. The learning experience should be as joyful and interesting as the initial discovery.

This work uses neuroscience studies to apply a game design based education. The neuropedagogical approach results in an effective and lasting learning process of working and theoretical knowledge. The engagement of the students is achieved by leading them through discovery and experimentation with the purpose of building a storytelling game of their learning path. The learning comes from first hand contact with their own scientific experience and an attempt to grasp understanding from the nearby reality. Meanwhile, the need to produce a published version of their work, enhances the commitment to give their best, envisaging the social purpose of their own effort. The proactivity and protagonism of the student, in charge of his/her own education and responsible for others, is the main drive and strength of this proposal. Producing a game to educate his/her peers, is in itself a ludic activity that requires digital and artistic skills, enhancing self esteem and imbuing values of social awareness into the student. This proposal guides the student through a neuroscientific based process of learning, resulting in a deep understanding and professing of the encircling reality. The central instrument employed is the development of digital games to represent and present the acquired knowledge and the story of obtaining it. This form of education centers on proactive learning of knowledge and skills and imbues the student into the role of building a better society.

\section{Digital and Scientific Literacy: Genetics and Computational Neuropedagogy}

The new government directive for education, the $B N C C$, requires that education goes beyond memorizing subject contents to emphasize critical thinking and creativity. Considering this demand, and perceived during the execution of pedagogical activities, we found ourselves facing the following research question: How to promote the convergence between the interest awakened by Science and knowledge-based verification, enabling an active and meaningful learning experience aligned with the BNCC in basic education?

According to the present research, we validated the hypothesis that it is possible to promote genetics in a playful and challenging way for students of basic education through games and digital technologies, allowing the convergence between interest in the subject and understanding expression of acquired knowledge. It was proved by the following tests and school projects held after the game development.

\subsection{Literature Review}

\subsubsection{Genetics Teaching and Learning Process}

Amabis and Martho (2001) states that genetics is the branch of biology that studies species' characteristics transmission mechanisms passed from generation to generation. In Brazil, genetics is part of the biology curriculum taught in the 3rd grade in high school. For Moura et al. (2013), the study of genetics is still considered abstract and distant from the reality in which students take part in. Oca (2005) reports that genetics contents in public basic education are often considered difficult and uninteresting, not allowing students to correlate topics such as cell cycle, constitution, and DNA molecule functioning, among others addressed in the classroom, which are the basis of technology creations such as transgenic for instance.

Regarding the importance of understanding genetics, Jrasilchic (2000) affirms that biology classes enable students to assimilate, reflect, criticize and deepen their knowledge about biological processes and understand their importance in the construction of technology that generates products that will benefit (or not) society. Biology classes should also allow students to develop skills for understanding, observing, systematizing, elaborating, and re-elaborating facts.

Borges et al. (2006), Lima et al. (2007), and Silva et al. (2008) demonstrate that a large portion of Brazilian students who leaves high school failed to understand that Mendel's laws are not just letters that combine at an intersection, but that the letters represent the nucleotide sequences, which represent the genes. These are present on chromosomes, and they secrete during meiosis for the formation of gametes. More than that, Mendel's laws are a basis for understanding hereditary characteristics passed down from generation to generation, such as the appearance in one generation of the 
offspring of a specific disease, or else to produce an animals' offspring of economic interests.

\subsubsection{Computational Neuropedagogy and Games}

Carabetta (2010) attests educators must plan didactic procedures that instigate students to reflect and apply classroom data contents in solving problems. In this sense, Computational Neuropedagogy, as a transdisciplinary science, provides the foundation for a pedagogical proposal based on Neuroscience and games, which fascinate young people and can help with teaching-learning processes.

In the scope of Computational Neuropedagogy, in Marques et al. (2015), we have the core for understanding cognitive aspects of learning through games. In Marques et al. (2019), we find support in a neuroscientific-pedagogical model of Education through digital games and in Rodrigues (2018) a neuropedagogical computational strategy to promote development of young people in criminal high-risk areas and social vulnerability.

With regard to taking part into society, this project embraces two public schools, including these students in the digital world and assuming that universities must also focus on providing a social role. As information technology is essential in modern life as a tool for work, communication, and even the contemporary way of life, its acknowledgment results in a broader social insertion into digital citizenship.

\section{Related Works}

Fabricio et al. (2006) carried out an experiment with 136 students in the 3rd grade in high school at public state schools in Recife's metropolitan region, Pernambuco, where they assessed the public's knowledge of Mendel's laws and discovered that the majority of students interviewees did not know how to define a gene, did not know how to associate the gene with the laws and the vast majority associated the laws only with the letters that symbolically and didactically represent the genes during segregation in meiosis, proving students' difficulties with the content. In this work, we identified the importance of logical thinking to enable the student to perceive the existing relationships between the transmission of hereditary characteristics and the process of cell division. For this reason, we consider logical reasoning and the development of skills related to computational thinking as essential in the elaboration of our proposal.

Brão et al. (2015) investigate playful possibilities in genetics teaching and conclude from experience with Biotecnétika that games stimulate greater commitment and dedication of students in the content covered. This work presented a concern to verify if there was a change after the game activity. In our proposal, this concern was also considered. For this purpose we performed cognitive tracking.
Souza et al. (2019) report the development experience of the Amigoácido ${ }^{1}$, which uses gamification techniques to assist high school students in learning genetic code in a fun way. This research shares the view that games should be used to promote a break in the educational paradigm, as the authors emphasize that the use of technologies in the classroom should not be limited to the repetition of traditional teaching methods. To break the paradigm, our proposal contemplates the student as an active subject in the construction of their knowledge.

Our proposal differs from authorship since, in our project, the game is an artifact developed by students to enable autonomy, responsibility for learning and protagonism. As advocated by BNCC's 5th skill, it incites understanding, uses and creates digital information and communication technologies in a critical, meaningful, reflective and ethical manner in various social practices (including school ones): (a) Communicating - accessing and disseminating information; (b) Producing knowledge solving problems and exercising protagonism and authorship in personal and collective life.

\section{Pedagogical Process based on System Engineering}

\subsection{Method}

Teixeira and Neto (2017) understand action research as a possibility of interventional nature method, which was selected for this project's conception. According to Rossi's (2018) definition, we consider this work as part of a critical action research since it results from a process that values cognitive construction of experience. It is supported by collective critical reflection, with a view to emancipation of individuals and conditions that the collective finds oppressive.

In the project's execution, we used the pedagogical methodology proposed by Marques (2017) for the design and construction of games. Besides, we worked with the Metacognitive Pedagogical Thread of Rodrigues (2018) for metacognitive mediation and application as a pedagogical process based on systems engineering. The pedagogical methodologies and process will be detailed in section 4 .

Together with the aforementioned methodologies, we also used Eduscrum ${ }^{2}$, an adaptation of the agile Scrum methodology from the software development industry. An equivalent view was adopted as a development methodology during the game code creation.

We have chosen the Scrum methodology to motivate engagement of young people in creating and programming tasks, which is a great challenge, as they seek an immediate result of high quality that actually requires a longer period of learning. In this way, we can use the concept of agility to provide students with conditions to create a project in a few months throughout the school term.

\footnotetext{
${ }^{1}$ In Brazilian Portuguese, this name contains a wordplay to indicate that amino acids are our friends.

2 https://www.eduscrum.nl/about/eduscrum
} 


\subsection{Sample Description}

Research was carried out with 53 students from three high school classes at "Escola Estadual Marechal Zenóbio da Costa", located in the city of Nilópolis, Baixada Fluminense. 20 Former students acted as knowledge multipliers for other 7th and 8th grade middle school students from the "Escola Municipal Jornalista Escritor Daniel Piza", located in Complexo da Pedreira, which encompasses neighbors that have the lowest human development indexes in Rio de Janeiro's entire city.

It was necessary to institution permission and previous authorizations from the legal guardians of all underage executors involved to carry out the project.

The sample is non-probabilistic, composed of voluntary participants. Development and application of the genetic game was one of the research accomplishments under the Super Python project, in partnership with Federal University of Rio de Janeiro.

The project is directed to children and adolescents who live in conflict areas, with high social vulnerability, aiming to promote an inclusive education that encourages science through games, playfulness and technologies. We believe that it is no longer possible to endure teaching content in an expositive and isolated way with no current socio-historical context. We need to use verbal, non-verbal, mixed, plural texts and language oriented to personal, social and expressive use. Allowing us the conditions to encourage digital literacy and, accordingly, scientific literacy.

\subsection{The Super Python Project}

Super Python is a programming language project for children and young people to create several school subject games developed in Python. It was created to harness children and young people's talent and creativity in the production of interactive stories and games. By creating these, young people can feel the satisfaction of making their playful world come true, at the same time that exciting material can be appreciated and enjoyed by their peers.

It is a web development environment written in Brython, developed and maintained by the Educational Systems Automation Laboratory at the Federal University of Rio de Janeiro. The project allows elementary and middle school students to learn Python together while developing games and dealing with the subject chosen by the teacher.

This project, approved by the Brazilian Computer Society, is already in its 6th year of application, serving students from public schools in the city and state of Rio de Janeiro. During the project, we found out that game development has been defined as an innovative and challenging pedagogical practice, as it requires multidisciplinary knowledge from students and teachers. It is also capable of activating students' mental functions that help them think creatively, surpassing mere content memorization.

\subsection{Intrinsic Process}

In our research laboratory, we developed and applied a pedagogical approach based on creating systems, exploring intrinsic transdisciplinary processes and adapting activity sequencing to a cognitive improvement process.

The approach presented in Figure 1 emphasizes the distribution of roles among students as an important characteristic for several executive functions' in cognitive activation.

Based on Majolino (2000) and Royall (2002), we believe that student's relay between these roles improves attention, context transition and inhibitory control.

The sequence of activities follows the methodology guidelines of cognitive microgenesis. This methodology activates the cognitive engagement process in which the internal acquisition mechanism performs, optimizing the ability to understand and incorporate mental skills. The pedagogical architecture unfolds in a set of subprocesses that have been untangled into the Neuropedagogical Thread. Neuropedagogical Thread was proposed by Rodrigues (2018) and has 5 phases, as shown in Figure 2.

In phase 0 (Population of the Imaginary - Intervention), we seek connection between the physical and cultural world to develop cognition. Thus, we provide input to the imaginary through various activities that stimulate students' cognitive imagery. We use games, Internet research, practical laboratory classes and tours. As an example of this phase we charted a coach to visit Oswaldo Cruz Foundation (FIOCRUZ), a research and development institution in biological sciences located in Rio de Janeiro.

In phase 1 (Presentation of Real Knowledge Object's disconnected elements), we present real disconnected elements, such as materials for experiments displayed on the laboratory bench and software in computer classes. To illustrate this phase the following experiments were carried out in the science laboratory: the card game of living beings, fossils, DNA extraction, natural selection, and the Galapagos finches and study of heredity. At this point, we presented the problem, causing an internal and specific mobilization to recruit areas that activate problem-solving in the brain. According to Inhelder (1996), family schemes, pre-existing representations in the brain collection to recruit prototypical schemes, are activated to solve a problem. This generates innovative schemes, which are new cognitive schemes that arise from the subject's interaction with a new problem. In this phase, we also highlight formalization of thought which has biological maturation followed by interaction with the environment, promoting new stages of development according to Piaget (1987).

From the moment a student connects parts of the Real Knowledge Object, he begins a process of understanding. Forming new knowledge, thus triggering the beginning of Real Knowledge Object - genuine knowledge about a particular subject - constructionism, a term described by Papert as the development of learning through construction or elaboration of something.

In phase 2 (Expression - Interpretation - Verbalization), speech in the expressive and impressive modalities (Luria, 
1981) is used as a stimulus to metacognition. This stimulus aims to awaken students' awareness and self-criticism in understanding the learning process source to become active and protagonists in their own development. Thus, we realized that, in IT activities, questions such as "Why did you do that?" and "Why did you do it that way?" helped the individual to understand his form of interaction with the device and encouraged him to explore more and more the digital tools. When provoked with a question like: "Could you do it any other way?" We noticed a tendency to reduce fear in facing situations. So students started to explore other possibilities on the computer.

In phase 3 (Intervention - Interpretation - New Construction), the teacher asks: If you change these components, will the result be the same? The teacher records the response. For evaluation, the prognoses adapted according to the transitivity between language, mathematics, and science, applied by Marques (2017) were used.
In phase 4 (Transitivity in different areas of knowledge - Evaluation), the teacher asks: "What did you do?" and "Is this knowledge applied only in this discipline?" Finally, he encourages the sharing of knowledge: "Now transmit that knowledge to other groups."

In all phases of the Metacognitive Pedagogical Conducting Thread, Directed Elaboration Technique questions about the Real Knowledge Object are made to activate the learning process - and Computational Thinking were applied.

\section{Conducting the Project}

We conducted the project based on Rodrigues et al. (2019) cornerstones, which are: Digital Literacy using Digital Information and Communication Technologies (TDIC). At this stage, unplugged computing and analogic exercises can also be used to develop computational thinking;

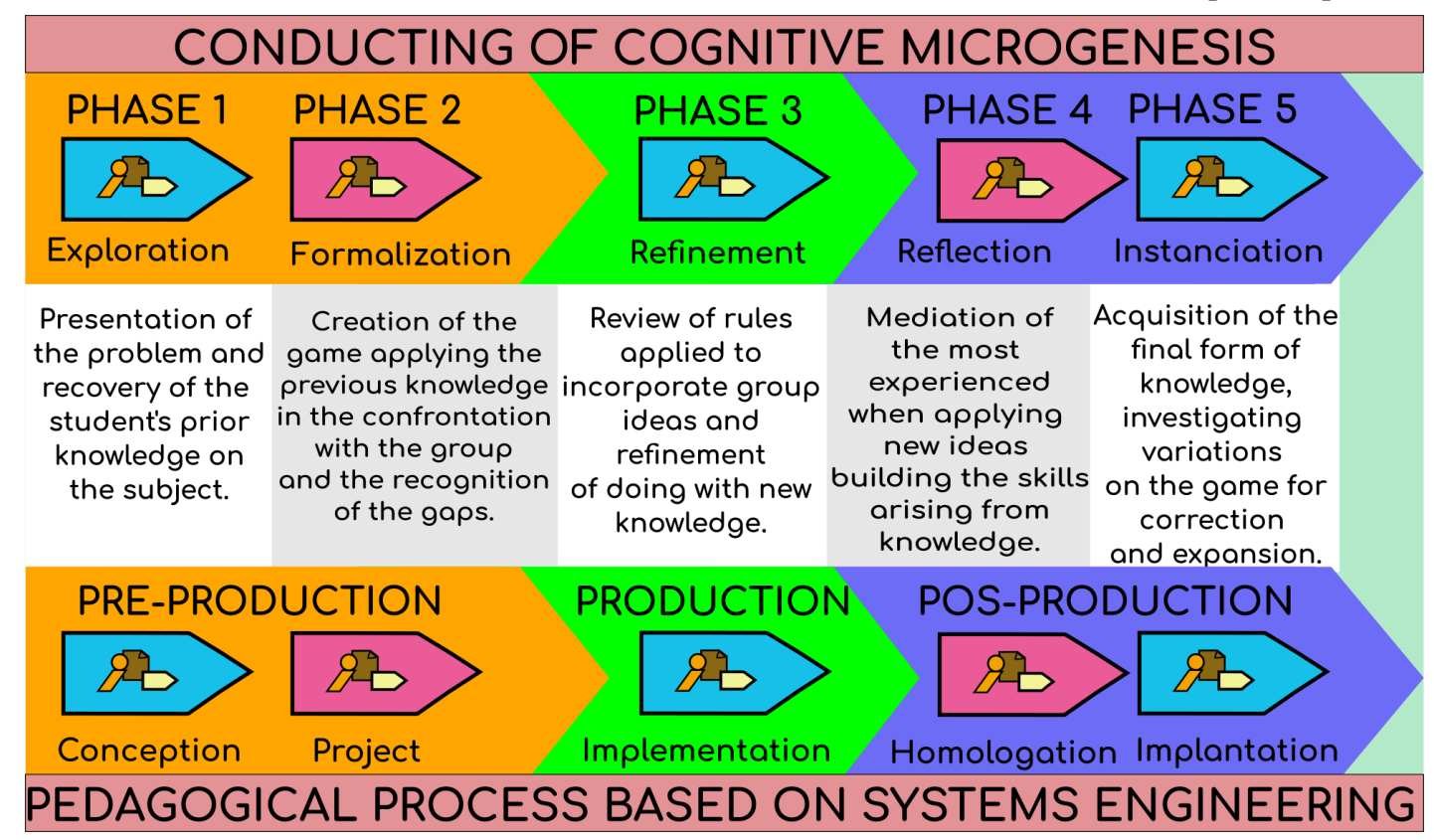

Figure 1 - Pedagogical process based on Systems Engineering

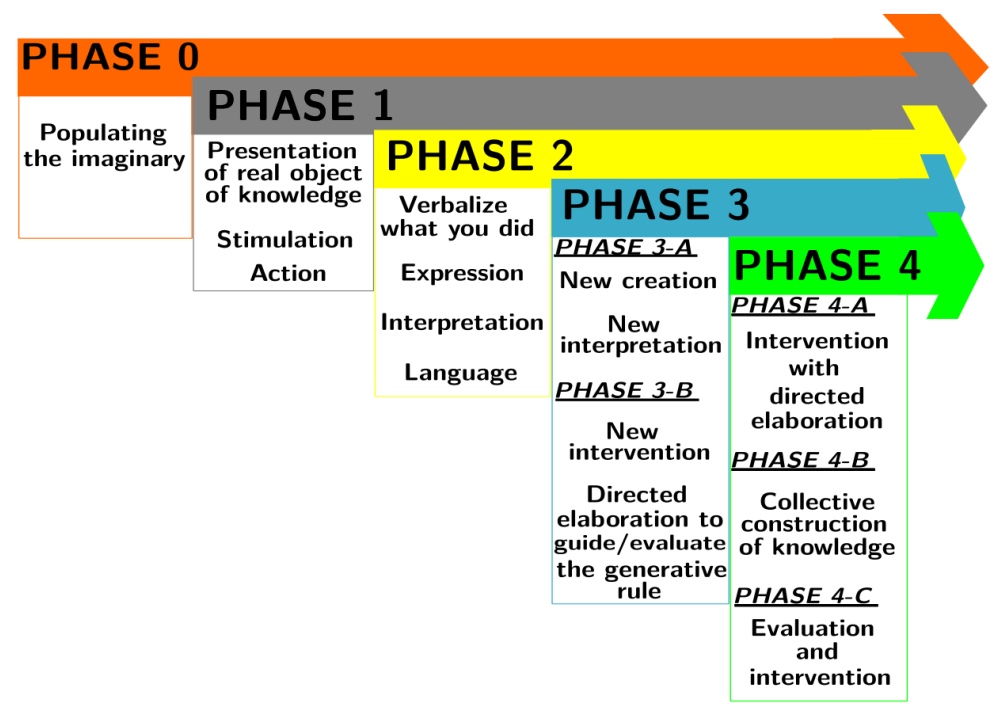

Figure 2 - Phases of Neuropedagogical Thread (Rodrigues, 2018) 
Neuropedagogical Approach for cognition and metacognition development of the children involved; Teaching the Methodology of Designing intelligent games and Teaching Programming Language with practical activities; Multiplication of knowledge acquired through collaborative game construction activities. Such steps aim to develop games that integrate playful, meaningful teaching-learning methodology based on Neuroscience and Systems Engineering for students of basic education.

Boehm's spiral model cornerstones representation in Figure 3 indicates an evolutionary process, such as cognitive microgenesis. It is an iterative model with successive refinements that assumes continuous digital literacy to meet constant socio-technical changes. This model can include different actions according to the students' needs. Therefore, in the execution of this research, we approached scientific literacy concomitantly with digital literacy, using computational thinking and scientific thinking to lead students to metacognition through game development using a pedagogical process based on engineering of systems.

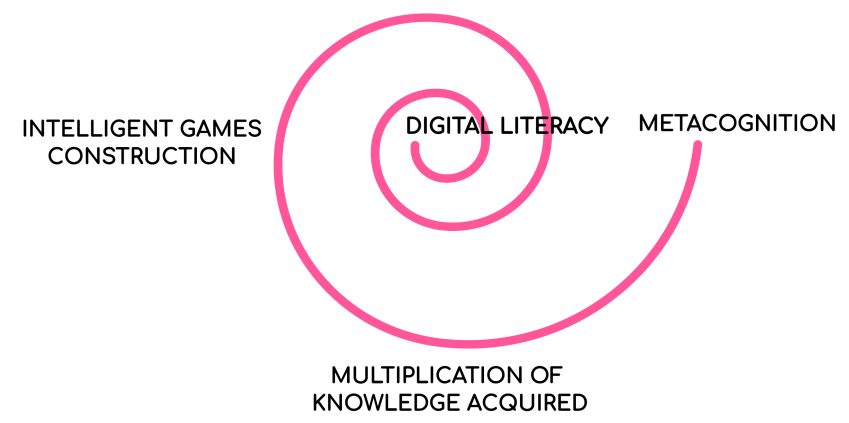

Figure 3 - Boehm representation work of cornerstones

With this work, we realized that the literacy stage could cover concomitantly different literacy types, such as digital literacy, media, scientific, literary, among others. Working with digital and scientific literacy was very promising for formative learning evaluation. We initially performed recreational activities with board games and unplugged computing to attract students' interest and develop computational thinking to carry out this stage. Subsequently, we conducted basic activities of Informatics and Introduction to programming.

Students learned to work with Prezzi for presentations; and Google Docs for storing game narratives, images, and scenarios. We used Google Maps to demonstrate Darwin's journey around the world and the Galapagos Islands' location. The first programming challenges were implemented on the Flying Circus Platform - The Flying Circus of Python Programming, available at http://circus.isby.us and through the game Kwarwp available at http://supygirls.pythonanywhere.com / kwarwp.

We used the Super Python project's environment for the game development that has a graphic library in which each student builds a game module using only a browser. Students' code creation is done by importing libraries, starting with the most basic ones, which allows setting up of scenes, inclusion of text and insertion of elements in scenes. Some scenes were produced using Minecraft, an independent game that allows creation of scenes using assembly blocks.

To insert photographs or drawings in the code developed platform; we used Imgur, a free image-hosting server. Thus, the media are inserted from plugin network addresses in navigation browsers.

We also widely instigated insertion of photographs and drawings produced by students themselves. In this project, students used photographs taken with their smartphones during the FIOCRUZ tour.

After using the Conductive Thread for main problem understanding and discussion, we prepared the intelligent game construction. According to Marques (2017), intelligent games are developed through neuroscientific processes similar to pedagogical ones based on systems engineering introduction. In this case, we provided instructions based on Bloom's Taxonomy, a hierarchical organizational structure of educational aims.

Table 1 presents an example of an instruction used to stimulate students' imagination so they could collaboratively create game questions.

Table 1. Mediation example for the creation of main quests and side quests

Dimensions Sensibility deoxyribonucleic acid (DNA) Understand

PROPOSAL: Create a story in which the player needs to understand the DNA constitution to continue playing; in this story the visual sensation can help you in a puzzle-solving situation, for example.

Mediation questions were composed of genetics items elaborated with several questions whose answers lead to an in-depth knowledge of the main theme.

After this stage of understanding the problem and creating the main and side quests, there were also activities to teach the methodology of designing smart games and teaching Python programming language with practical activities. In this step, we used Marques-Oliveira methodology (Marques et al., 2019). It should be noted that the produced game used part of a graphic environment previously developed in a project called Crimes \& Codes, where images of the scene were extracted from the game mentioned above. In this game students designed the set with the help of Minecraft.

Therefore, the game developed by students in this proposal, entitled "Agents of E.S.C.O.L.A. - Mystery at the Geneticist's House" is considered a Crimes \& Codes franchise and its executable prototype brings a mixture of scenes that were not only built-in Minecraft but also produced with photographs taken by them in the composition of a narrative that involves genetics in a 
criminal investigation. Figure 4 presents part of the game scenario.

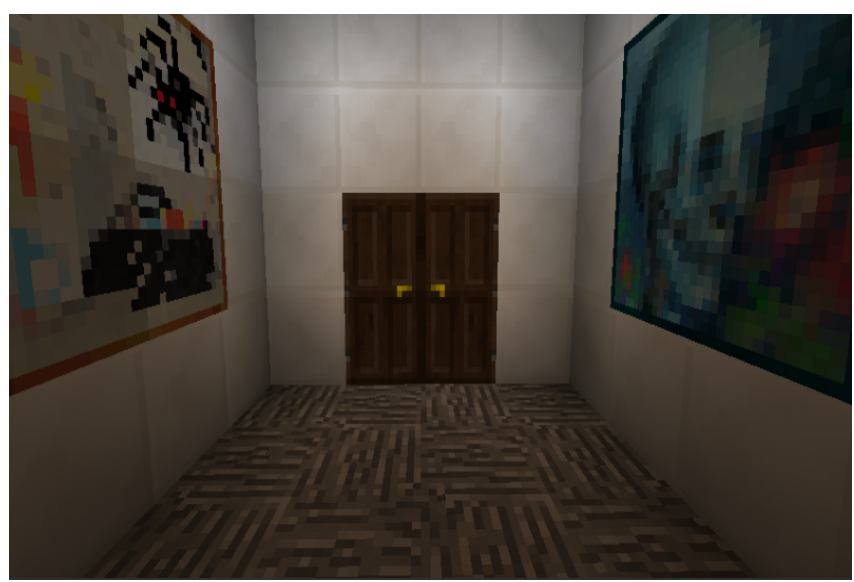

Figure 4 - Students game design settings, which involves an investigation mystery about genetics

The design work started by taking a survey on the theory involved. After that, we initiated dimensional modelling as the theoretical framework was already established. In this step, we determined the dimensions of knowledge and cognition, identifying significant intervals where these dimensions were relevant to the scope of the game. Then, we moved on to the creative process, where the game's initial art was paired with specific requirements, defining playable episodes.

As part of the work, students developed a computational sieve $^{3}$, which, according to Marques (2017), is a detailed document that enables data capturing. Pointing out relevant dimensions to the mental processes investigation, it stores important events, creating a manageable collection of data that can be treated to generate useful information.

The development also had GDD (Game Design Document) documentation, which according to Viana et al. (2017), has as main objective to outline everything that will be present and usable in the game regarding other phases of production or post-production. Its main relationship is with gameplay and how characters interact with the game world and other elements.

The game plot was as follows: Scientist Rosalinda Franco rediscovers a secret kept by her great aunt Rosalind Franklin. However, it disappears mysteriously. In her empty house, a notebook stands out as several pages were missing. On the first page, there is a note from her about finding pages in a genetics book and this is the lead that will help players to clarify the case.

Based on the three main elements used by the Super Python project, namely: scene, text and element, as shown in Figure 5, the game design activity stimulates students' creativity.

\footnotetext{
${ }^{3}$ https://activufrj.nce.ufrj.br/wiki/Kwarwp/Crivo_Computacional
}

It is worth emphasizing how important it is to discuss with students the differences between classic narratives and narratives for games, presenting elements such as interactivity, immersion, and non-linearity. Considering the last one mentioned as a crucial characteristic whereas game narrative depends on the choices made by the players which makes possibility projections a main skill for game developers.

Therefore, we consider game programming a rich experience for students: those who program a game create possibilities for stories that other people will be able to tell (or retell) depending on their playing choices (Machado et al., 2016).

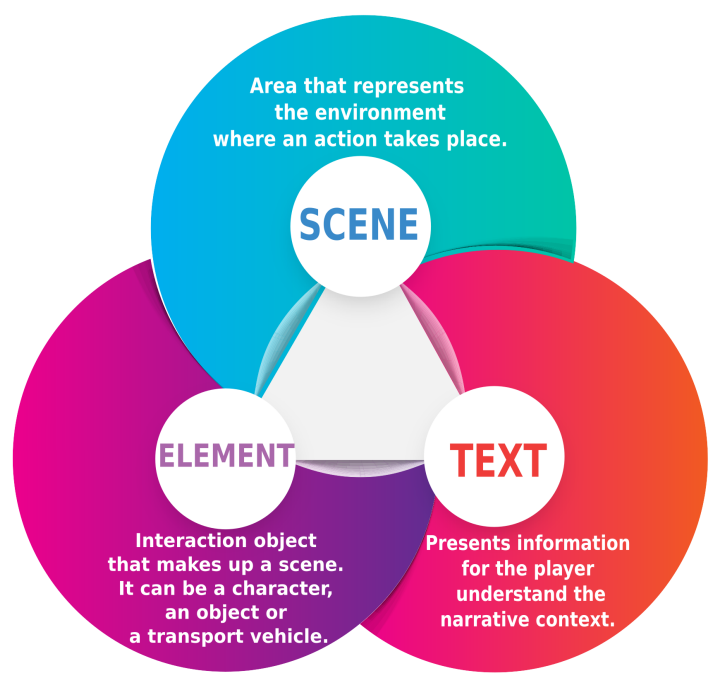

Figure 5 - Pillars of building games in Super Python project

Table 2 shows how students creatively built characters, scenes and elements for the game. Such elements allow students to exercise narrative skills, because they are concepts from Literature that are also applied in scripts of game development. It is important to note that students on ActivUFRJ platform were the ones who produced the stories.

Table 2.Project GDD section drawn up by the students

\section{CHARACTERS}

\begin{tabular}{|l|l|}
\hline Rosalinda & $\begin{array}{l}\text { Scientist Rosalinda Franco rediscovers a } \\
\text { secret kept by her great aunt Rosalind } \\
\text { Franklin. She owns the mysterious house } \\
\text { and guides the visitor through a book hunt. }\end{array}$ \\
\hline Visitor & $\begin{array}{l}\text { The anonymous visitor is looking for a } \\
\text { cure that he believes is in Rosalinda's } \\
\text { home. He has an incurable genetic disease } \\
\text { and this is his motivation to move } \\
\text { forward, hence he is willing to face all } \\
\text { challenges to be healed in his journey. The } \\
\text { player represents this character. }\end{array}$ \\
\hline The antagonist & $\begin{array}{l}\text { The Antagonist is a nefarious character } \\
\text { who threatens Rosalinda in an attempt to } \\
\text { obtain her discovery. He is allegedly } \\
\text { responsible for Rosalinda's disappearance. }\end{array}$ \\
\hline
\end{tabular}




\begin{tabular}{|c|c|}
\hline L.E.N.I.A.H & $\begin{array}{l}\text { It is the Natural Engineering Laboratory } \\
\text { with Holographic Artificial Intelligence. } \\
\text { This robotic laboratory is one of } \\
\text { Rosalinda's creations. It is spread all over } \\
\text { the house but has a coordinated } \\
\text { intelligence between its parts. It offers } \\
\text { challenges, but, at the same time, } \\
\text { instruments for the visitor to be able to } \\
\text { perform their tasks. }\end{array}$ \\
\hline \multicolumn{2}{|l|}{ SETTINGS } \\
\hline $\begin{array}{l}\text { Rosalindas' } \\
\text { house }\end{array}$ & $\begin{array}{l}\text { It is the main setting of the game. The } \\
\text { visitor walks around the house looking for } \\
\text { pages, bottles and other objects that will } \\
\text { help to unravel the mystery. }\end{array}$ \\
\hline $\begin{array}{l}\text { Oswaldo Cruz } \\
\text { Foundation } \\
\text { (FIOCRUZ) }\end{array}$ & $\begin{array}{l}\text { Some situations will bring to the visitor's } \\
\text { memory a glimpse of a day he went for a } \\
\text { tour at FIOCRUZ. In this scene, some } \\
\text { important information will help the visitor } \\
\text { in his search. }\end{array}$ \\
\hline $\begin{array}{l}\text { LENIAH's } \\
\text { spaces }\end{array}$ & $\begin{array}{l}\text { The character L.E.N.I.A.H. will manifest } \\
\text { in several locations that give access to this } \\
\text { robotic laboratory. In these spaces, it will } \\
\text { be possible to build new substances that } \\
\text { will help to continue the visitor's search } \\
\text { for the book. }\end{array}$ \\
\hline $\begin{array}{l}\text { Antagonist's } \\
\text { hideout }\end{array}$ & $\begin{array}{l}\text { Somewhere in the house the visitor will } \\
\text { have access to the antagonist's hideout and } \\
\text { finally all the mystery will be solved. }\end{array}$ \\
\hline \multicolumn{2}{|l|}{ ELEMENTS } \\
\hline Genetics Book & $\begin{array}{l}\text { It is the main artifact of the game. It is } \\
\text { found in the second room and remains in } \\
\text { the inventory until the end of the game. } \\
\text { They have all the clues and instructions to } \\
\text { move on in the game and, finally, unravel } \\
\text { the mystery. }\end{array}$ \\
\hline Lost pages & $\begin{array}{l}\text { The book is incomplete and several pages } \\
\text { are scattered throughout the house. } \\
\text { Finding a few pages is a challenge itself. } \\
\text { They contain important clues and } \\
\text { sometimes secondary objects. }\end{array}$ \\
\hline $\begin{array}{l}\text { Laboratory } \\
\text { flasks }\end{array}$ & $\begin{array}{l}\text { Many of L.E.N.I.A.H's products end up } \\
\text { packed in laboratory flasks that will be } \\
\text { used in some game tasks. }\end{array}$ \\
\hline $\begin{array}{l}\text { Genetically } \\
\text { modified } \\
\text { bacteria }\end{array}$ & $\begin{array}{l}\text { Transgenic bacteria can be built in } \\
\text { L.E.N.I.A.H to produce some substance. } \\
\text { To modify these bacteria, the player will } \\
\text { have to learn how to manipulate the DNA } \\
\text { so that a certain substance starts to be built } \\
\text { by the bacteria. }\end{array}$ \\
\hline
\end{tabular}

Multiplication of acquired knowledge is a pillar in the methodology. In this sense, high school students became monitors for other students at the end of their training period, which occurred during the school year every once a week. They used the game to share knowledge, enabling protagonism and social functioning while producing it collaboratively.

\section{Results}

\subsection{The resulting artifact}

Students were able to materialize their playful world and imagination at the same time they produced an executable prototype ${ }^{4}$, exemplified in Figure 6 and Figure 7, which was appreciated and enjoyed by their peers. Each scene has a story based on the dimensions established for the game and developed by a pair of high school students, guided by graduate students and the Science teacher. In the project's execution, the main artifact devised by the students was the genetics book.

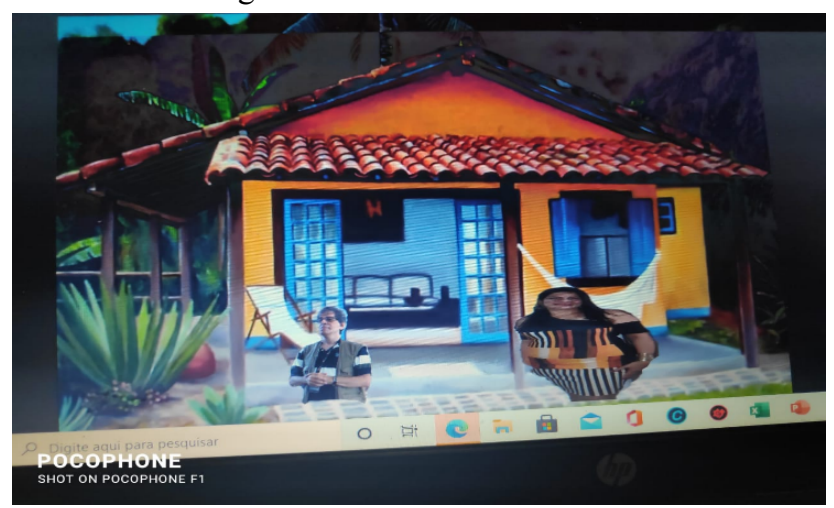

Figure 6 - A scene of the game

The text produced by the students to introduce the game was:

"Dear visitor, sorry for the intrusion at your leisure; I hope to count on your help. If you found this book, it is because a crime happened in this house. Please find the other pages, which for security, were scattered throughout this house. And for double security, the information was covered by puzzles. Please find the information so we can solve this mystery together."

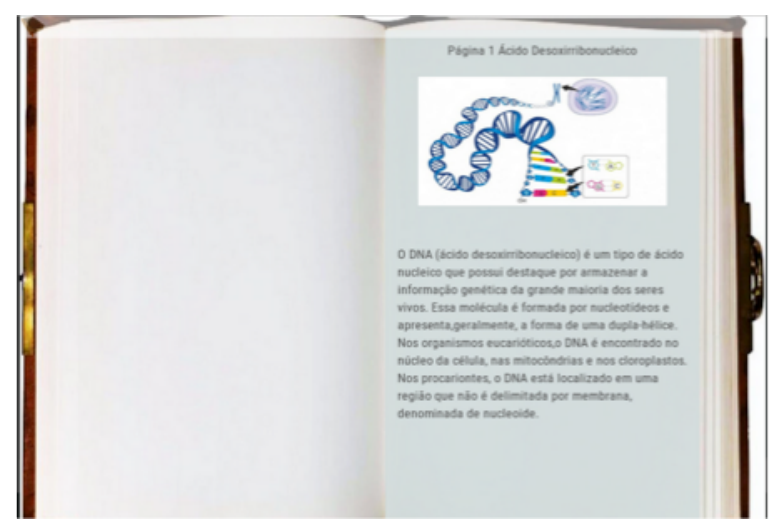

Figure 7 - Game genetics book

\subsection{Results from the Experience}

This work described the application and dissemination of a pedagogical process based on Systems Engineering. As seen, combining games with computing, pedagogical and

\footnotetext{
${ }^{4}$ http://supygirls.pythonanywhere.com/supygirls/gamer/dame/danae\#
} 
metacognition methodologies are a promising perspective for educational innovation.

As the teaching and learning process is heavily centered in game design and development, one important instrument of assessment is the programming platform Super Python. This platform saves each step of the development process in a Distributed Version Control System (DVCS), currently being assigned to Github.

From this registry we can assess the progress of the game being developed, but also it can be used to assess learning skills improvements. According to Marques (2017), evaluation of learning skills can be observed through a subconscious effect called Microgenic Cognition Resonance. This effect occurs when the brain forms constructs that match the structure of the problem being analysed. The observable result is that motor actions related to the handling of the problem gets an accelerated factor, where time events get closer to each other as learning advances.
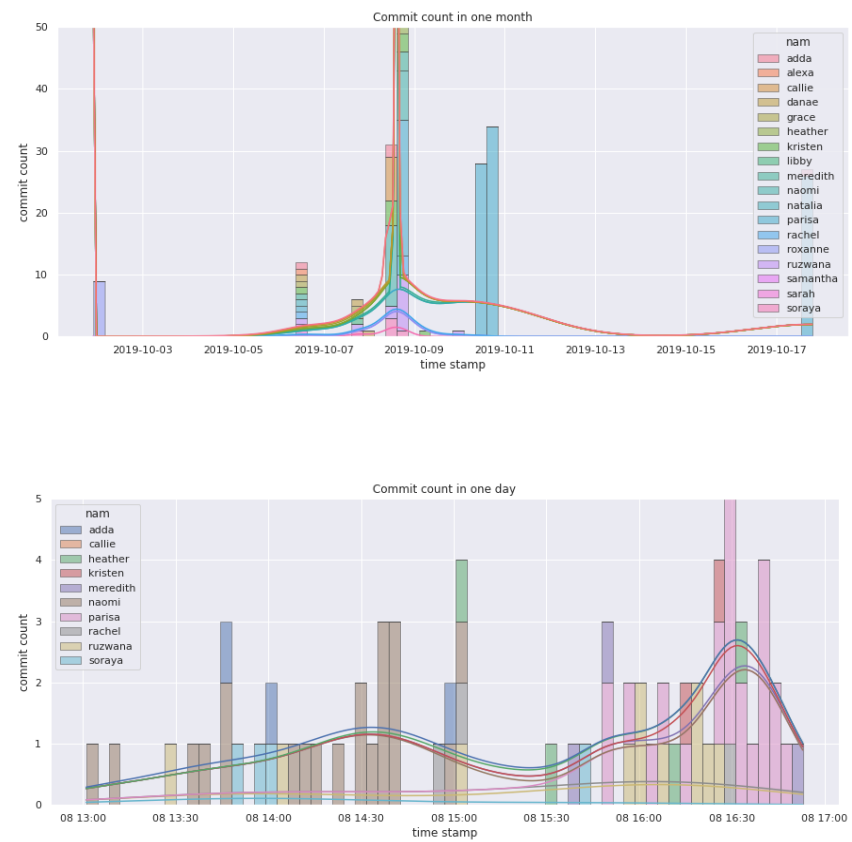

Figure 8 - Commit counts for game development.
The charts in Figure 8 show the progression of commits in a month and also in a highly productive day. The bursts of commits are an indication that learning is increasing and more changes are added to the game in a short period.
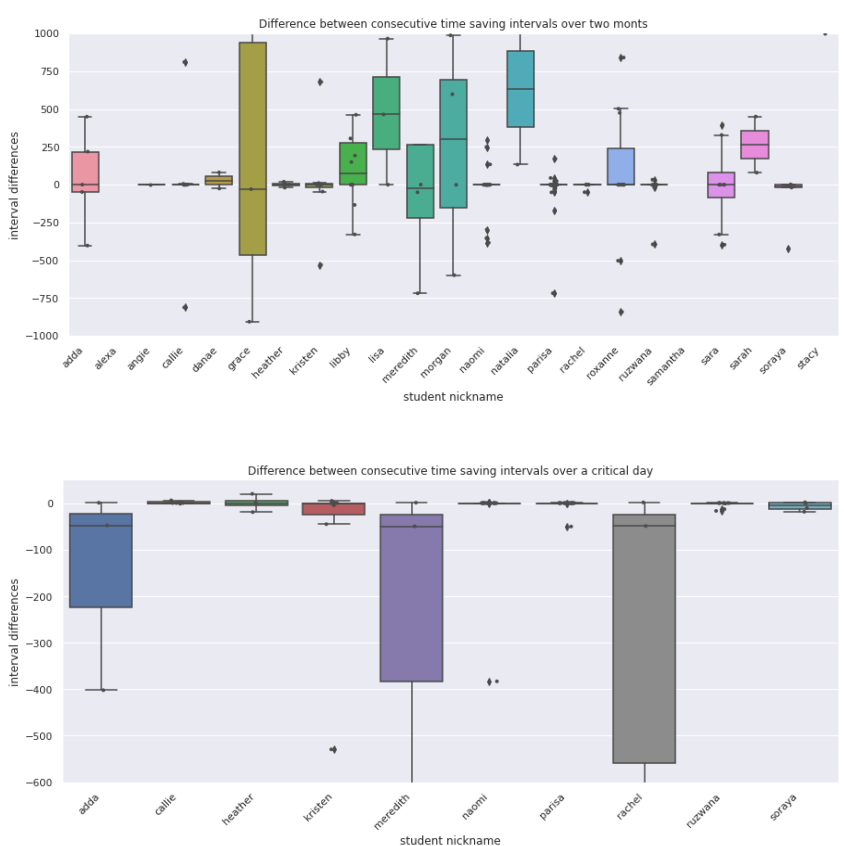

Figure 9. Differences between saving intervals

In Figure 9 there is an investigation about Microgenics Resonance. Over two months there are many students showing increasing rates of commits, observable by portions of the chart below zero (negative differences). In that critical day observed in Figure 8, most differences are negative, indicating an intensive period of cognitive acquisition.

The platform provides a game development framework to help with the construction of scenes, characters, properties, dialogs and mazes. Chart in Figure 10 shows the rate of improvements to the game at each time it is committed. 


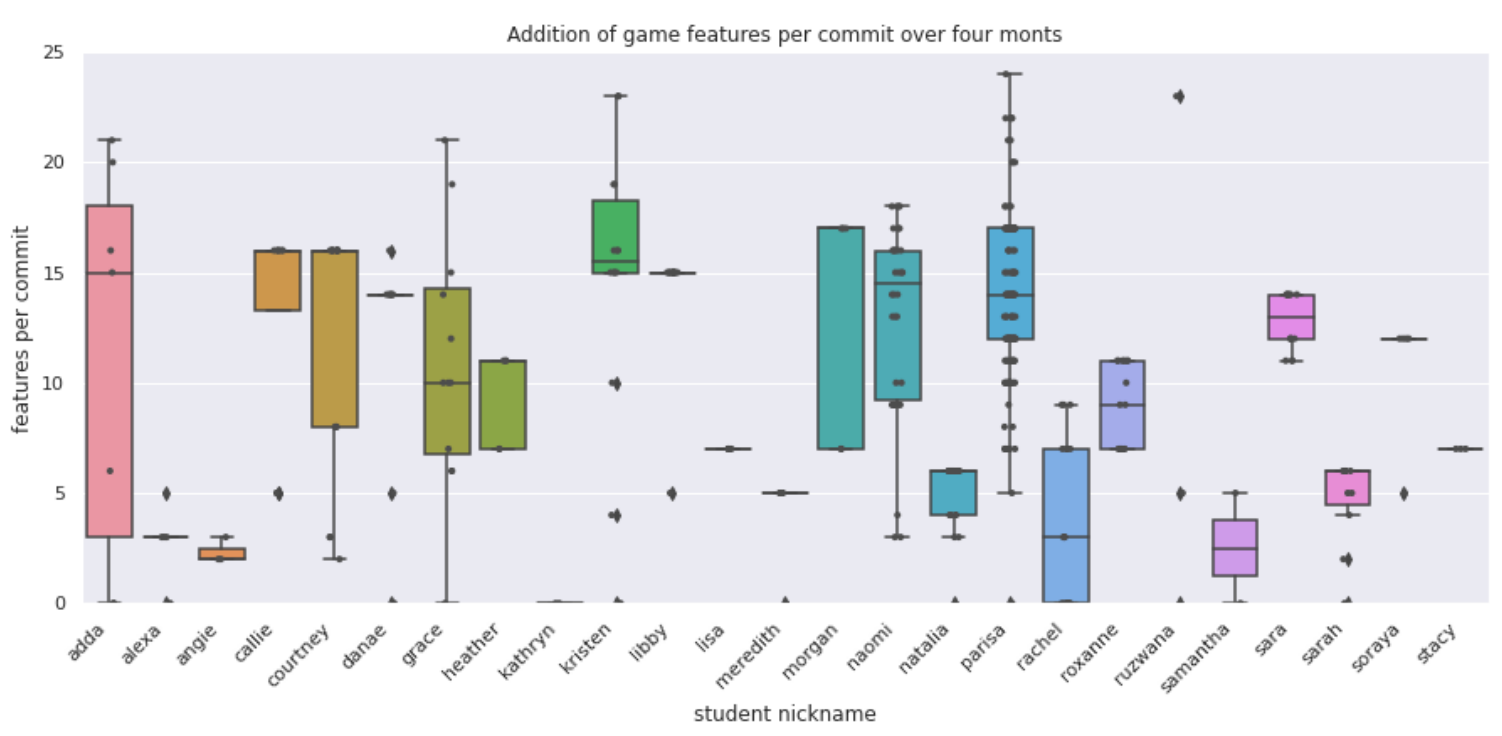

Figure 10 - Addition of game features

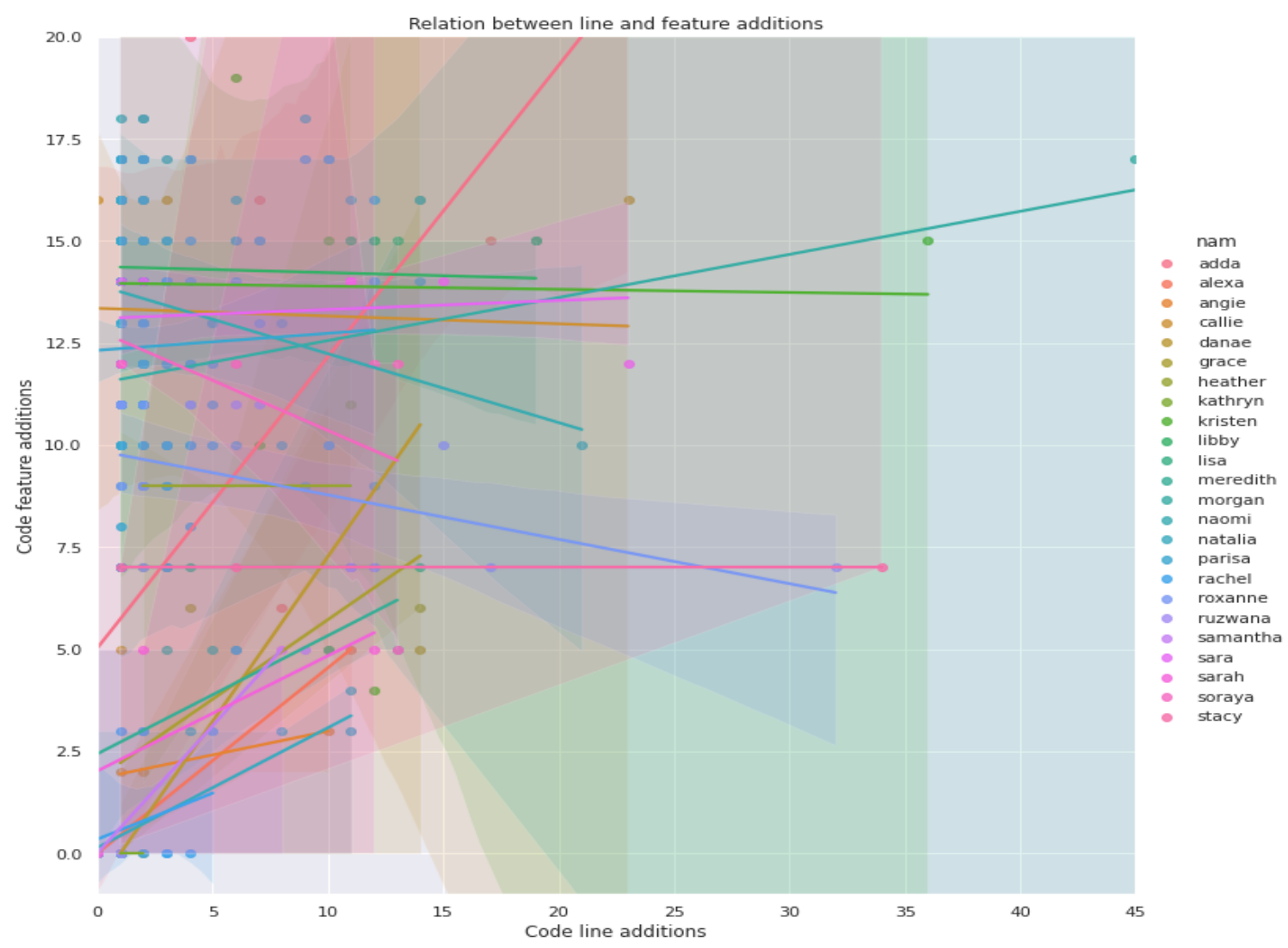

Figure 11 - Correlation between lines added and game features

These features were collected from the code posted in the commits over four months.

In Figure 11, the chart shows the correlation between lines added and new game features. Many students choose to improve game complexity as they expand the code. This points to the good results of the education process described, in particular the imaginary phase that entices the use of elaborate constructions.
In addition to the technological artifact produced, the paramount result is the student's development made possible by game construction activity. Through this study we confirmed that creating games in the educational field helps numerous skills development in students such as programming, storytelling and design.

Applying an implicit evaluation process using participant observation as an action research methodological procedure, it was possible to confirm this statement. 
The evaluation carried out at the end of the school period demonstrated that students obtained a positive result in their knowledge of genetics content verification. Thus, we achieved the objective of promoting convergence between the interest in science and the result's expression. We emphasize the importance of a broad formative assessment, which considers factors that are endogenous of pedagogical action results.

Regarding expression of acquired knowledge, it is worth mentioning that the game and all the documentation produced by students at the stage of conceiving were used in the formative evaluation. In this process, we also observed creativity, communication, collaboration, logical reasoning, problem-solving, abstract thinking, and resilience skills. Besides, we also observed youth protagonism and delight in building something with acquired knowledge, corroborating with constructionism as a motivational instrument.

As for the game's theme, it was well accepted by the project participants, who endeavored to understand concepts and competently carried out the activity. Therefore, we turned difficulty into motivation, as students felt driven to learn genetics as a result of building games.

At the end of the activities, we applied a survey to determine which class model students considered most pleasant and satisfying. Answers were unanimous: game creation classes were by far more attractive than any traditional expositive lesson.

In all respects of the process, a qualitative evaluation was carried out, which, according to Demo (2007), is of fundamental importance for the construction of a Quality Education focused on citizenship, formal and political competences. However, according to the same author, qualitative evaluation intends to overcome the quantitative one without abandoning it. From this vision, a Seminar was held at the end of the year, where the main theme was "Genetics and its implications for humanity", from which students were evaluated quantitatively.

Regarding the total number of students who were evaluated, we totaled 53 students, of whom 40 prefered game preparation methodology against 13 who prefered traditional methodology. In order to propose an exempt evaluation, biology teachers from other institutions were invited to evaluate oral presentations made by the group of students.

Evaluations were carried out from a form containing the following items: Identification, individual posture, clarity in the presentation, theoretical basis, cooperation between groups, formality of language in use, poster or slide presentation (aesthetics), and each item ranging from 0 to 10.

Groups that went through game making methodology scored a higher performance than those who opted for traditional education. Approximately $75 \%$ of students who preferred the innovative methodology performed better than those who preferred traditional education.

Another result that we consider important in educational terms is that students who were previously assessed as insufficient in traditional classes, later, accomplished the project activities in a highly satisfactory manner. With this outcome, it is crucial to use active learning methodologies and rethink school evaluation processes.

We also emphasize the importance of teacher continuous training and the need to guarantee and grant paid hours for educators to be fully dedicated to planning and executing educational projects like this in basic education, as this project required a long period of planning and training.

Regarding the protagonism of students, which we understand, according to the perspective of Costa (2000), as a way to help adolescents to build their autonomy through the generation of spaces and situations conducive to their creative, constructive, and solidary participation in solving real problems at school, in the community or even in wider social life, we found that the project developed was an effective possibility to enable this condition. Therefore, we consider games as tools for authentic participation. In addition to acting as creators, developers and multipliers for other students, the project participants made presentations at academic-scientific congresses. They also took part in the Python language programmers and enthusiasts community events inserted in the scientific literacy process that covers interest in engaging with scientific issues, not only in the recognition and explanation of phenomena but also concerning the consumption and circulation of knowledge in society.

As the works listed on section 3, despite different conduction and methodologies, we corroborate the pedagogical potential of games for the teaching-learning process of Genetics. However, we highlight the students' authorship and protagonism as fundamental in the perspective of a metacognitive education. In this sense, the pedagogical process based on systems engineering is a great contribution of this research.

Such strategy enables an interdisciplinary approach and assists in developing cognitive, digital, and socio-affective skills recommended by the BNCC.

As limitations of the implemented work, we highlight cognitive stagnation from Marques's (2017) perspective. Students from this sample, coming from socioeconomic vulnerability contexts, have restricted contact with different cultural manifestations. This was solved by the Metacognitive Pedagogical Conductive Thread, which recommends at a specific phase to populate the imaginary, maintained throughout the process.

We also had limitations with the technological infrastructure available at schools and the conditions of Internet access. Such limitations were mitigated through two measures: activities that were carried out with technological devices done in pairs, since there were not enough individual use devices - this measure also made it possible to encourage collaboration - and internet routing hosted from researchers' private connection when there was local lack of internet connection. Therefore, we reaffirm the need for investment in public policies to ensure effective implementation of information technology as a pedagogical tool in schools. 
Another limitation was obtaining financial support to take students on tours or scientific events. We surpassed this difficulty by applying for a collective financing request through the website Vakinha and suggesting it to anyone interested in financially supporting the project.

\subsection{Future work}

As future work, we intend to continue using games in basic education teaching-learning processes. Numerous curricular components can be directed to creating games. A future possibility is creating a collection of games with students themselves as available educational objects, which can be shared with students from other schools on their networks. We also intend to spread the methodology, assisting continuous training of Brazilian basic education teachers.

\section{Acknowledgements}

We thank the Brazilian National Research Council (CNPQ), by their financial support given to the knowledge multiplier students through the scientific initiation program for basic education students. Also, we want to thank the Principle Luiz Menezes Brito of "Escola Municipal Jornalista Escritor Daniel Piza". In memory of the Principle Anderson Roberto Silva of "Colégio Estadual Marechal Zenóbio da Costa". And recognize the Super Python extension project of the Federal University of Rio de Janeiro together with all the students and guardians daily involved in the development of this project.

\section{References}

Amabis, J. M., Martho, G. A. (2001). Conceitos de biologia. V3: genética, evolução e ecologia. Moderna, São Paulo.

Borges, K. G. D. B, Silva, C. C., Reis, A. R. H (2016). As dificuldades de aprendizagem das leis de Mendel por alunos do Ensino Médio de duas escolas de Manaus. In Anais do V Simpósio Nacional de Educação em Ciência e Tecnologia.Brasil. (2018). Base Nacional Comum Curricular. Brasília.

Brão, A. F. S., Pereira, A. M. T. B. (2015). Biotecnétika: Possibilidades do jogo no ensino de genética. In: Revista Electrónica de Enseñanza de las Ciencias V. 14, $\mathrm{n}^{\circ} 1$, pages 55-76.

Carabetta, V. J. Uma investigação microgenética sobre a internacionalização de conceitos de biologia por alunos do ensino médio. In Revista Contemporânea de Educação, V.5. n.10, pages 111-127.

Costa, A. (2000). Protagonismo juvenil: Adolescência, educação e participação democrática. Salvador, Fundação Odebrecht.

Fabrício, M. F. L, Jófili, Z. M. S, Semen, L. S. M., Leão, A. M. A. C. (2006). A compreensão das leis de Mendel por alunos de Biologia na Educação Básica e na Licenciatura. In Ensaio - Pesquisa e Educação em Ciências. v. 8, $\mathrm{n}^{\circ} 1$.

Fialho, W. C. G., Mendonça, S. (2020). O PISA como indicador de aprendizagem de Ciências. In Roteiro, v. 45, pages 1-24.
Inhelder, B. (1996). O desenrolar das descobertas da criança: pesquisa acerca das microgêneses cognitivas. Porto Alegre, Artes Médicas.

Krasilchik, M. (2000). Reformas e Realidade. O caso do ensino de Ciências. In São Paulo em perspectiva. V. 14, n.1, pages 85-93.

Lima, A., Pinton, M., Chaves, A. (2007). O entendimento e a imagem de três conceitos: DNA, gene e cromossomo no ensino médio. In VI Encontro Nacional de Pesquisa em Educação em Ciências. ABREPEC -SC.

Luria, A. R. (1981). Fundamentos de Neuropsicologia. São Paulo, Edusp.

Machado, R. M., Rodrigues, A. P. C., Fernandes, L. F. A., Motta, C. L. R. (2016). Ler, escrever e programar: atividades essenciais para o desenvolvimento cognitivo na era da informação. In Sanchez, J., editor, Nuevas Ideas en Informatica Educativa, V. 12, pages 511-516, Santiago de Chile.

Majolino,

E.

(2000) Funzioni esecutive: specificazione, aspetti neur oanatomico-funzionali e clinici. In SANNITA, W.G.; PISARRI, F.M. Introduzione alla riabilitazione cognitiva. Genova: Polo Didatico S. Anna Crotone, p.12-22.

Marques, C. V. M., Calil, E., Brasil, G. (2015). Game Inteligente: conceito e aplicação. In XIII Seminário SJEEC - Jogos Eletrônicos, Educação e Comunicação pages $162-171$.

Marques, C. V. M. (2017). EICA - Estruturas Internas Cognitivas Aprendentes: Um modelo NeuroComputacional aplicado à instância psíquica do sistema pessoa em espaços dimensionais. Tese de Doutorado. Universidade Federal do Rio de Janeiro, 2017.

Marques, C. V. M., Oliveira, C. E. T., Fernandes, R. M. M. (2019). Metodologia Neurocientífica-pedagógica aplicada à concepção de jogos para ativação das funções cognitivas de estudantes da educação básica. In Proceedings of VII Jornada de atualização em Informática na Educação. Brasília, 2019.

Moura, J., Deus, M. S. M., Gonçalves, N. M. N., Peron, A. (2013). Biologia/Genética: $O$ ensino de biologia com enfoque a genética das escolas públicas no Brasil. In Semina: Ciências Biológicas e da Saúde. v. 34, n.2.

Oca, I. C. M. (2010). ¿Qué aportes ofrece la investigación mas reciente sobre aprendizaje para fundamentar nuevas estrategias didácticas? In Revista Educación v. 19, pages 7-16.

Papert. S. (2008). A máquina das crianças: repensando a escola na era da informática. Trad. Sandra Costa. Porto Alegre, Artmed.

Piaget, J., Inhelder, B. (1983). Gênese das Estruturas lógico elementares. Rio de Janeiro, Zahar.

Piaget, J. (1987). O nascimento da inteligência na criança. 4. ed. Rio de Janeiro, LTC.

Rodrigues, A. P. C., Fernandes, R. M. M., Teixeira, L. L., Motta, C. L. R., Marques, C. V. M., Oliveira, C. E. T. (2019). O desenvolvimento de games como metodologia de ensino-aprendizagem e estratégia para promover o 
protagonismo juvenil. In Proceedings of Brazilian Symposium on computers in education, pages 853-862.

Demo, Pedro. Teoria e prática da avaliação qualitativa. Perspectivas Online 2007-2011, v. 1, n. 1, 2007.

Rodrigues, A. P. C. (2018). Fio Condutor Pedagógico Metacognitivo: uma Máquina de Estados Não Determinística para Elaboração de Games Inteligentes. Dissertação de Mestrado. Universidade Federal do Rio de Janeiro.

Rossi, R. (2018). Pesquisa-ação educacional: uma crítica ontológica. In Barbarói, Santa Cruz do Sul, n. 52, pages 170-181.

Royall, D. R., Lauterbach, E. C., Cummings, J. L., Reeve, A., Rummans, T. A., Kaufer, D. I., ... \& Coffey, C. E. (2002). Executive Control Function: A Review of Its Promise and Challenges for Clinical Research. A Report From the Committee on Research of the American Neuropsychiatric Association. The Journal of neuropsychiatry and clinical neurosciences, 14(4), 377405.

Silva, R. G., Zinzaretti, S., Lisoni, F. C. (2018). Percepção do conhecimento dos alunos do ensino médio do município de João Pessoa sobre temas emergentes em biotecnologia. In Experiências em Ensino de Ciências. V.13, no 1 . Pages 288-305.

Souza, J. Y. K., Vitória, A. B., Andrade, M. B., Simões, S. N. (2019). Um jogo educativo para o ensino do código genético de forma lúdica. In SBC Proceedings of SBGames 2019. pages 1288-1231.

Viana, Z. L., Ferraz, F., Jucá, P. M. (2017). Levantamento das Ferramentas e Necessidades da Indústria de Jogos na Escrita e Manutenção de Game Design Documents. In SBC Proceedings of SBGames 2017. pages 1156-1162.

Teixeira, P. M. M., Neto, J. M. (2017). Uma proposta de tipologia para pesquisas de natureza interventiva. In Ciência e Educação. Bauru, V. 23, nº 4, pages 1055-1076. 